\title{
KÖNYVISMERTETÉS
}

\section{Dr. Ádám Antal: Bölcseletek, vallások, jogi alapértékek}

Pécsi Tudományegyetem Állam- és Jogtudományi Kar, Pécs, 2015, 402 oldal

Ez a recenzió különösen rendhagyó - elsősorban abban a tekintetben, hogy rendkívül személyes. Persze - mondhatják az érdeklődő kollégák - minden recenzió személyes, hiszen a recenzens valamilyen kapcsolatban áll a véleményezett, bemutatott mü szerzőjével, vagy kedves kollégáról, főnökröl, vagy beosztottról van szó. Esetünkben mindez igaz. A recenzens az egyetemen Ádám professzor hálás és szorgalmas hallgatója, alkotmánybírói korszaka alatt tanácsadó munkatársa, kettejük viszonyában napjainkban is a tanítvány szerepkörében érzi jól magát. Gondolkodásában, majd amikor ő is főnök lett, megnyilvánulásaiban felbukkantak mesterének szavai, megoldásai, problémákra reagáló mondatai. Mechanikusan nem utánozta, ennél sokkal érdemibb volt kapcsolatuk, de hiányoztak a tartalmas, tanulságos beszélgetések.

A recenzens egy súlyos „,megpróbáltatásra” emlékszik, s ettől igazán személyes ez az írás. Az emlékezés ugyanis a bemutatás tárgyául szolgáló mü egyik elözményére vonatkozik. Még ahhoz a korszakhoz kapcsolódik, amikor Ádám professzor az értékekkel és a posztmodernitással kezdett foglalkozni. Ekkor jelent meg A posztmodernitás jogi sajátosságai címü tanulmánya. A recenzens - jogásztársai többségéhez hasonlóan (ez az, ami soha nem lehet vigasz! - mit nem tudnak a többiek, ez nem ment fel semmi alól sem) - nem értette a posztmoderitás kifejezés jelentését. Ebben nem igazán segítették a kor nagy filozófusai sem. Bár a recenzens kézbe vette Heller Ágnes és Lendvai L. Ferenc több írását is, de ezek a közjog világán edződött ember számára olvashatatlannak, vagy mondjuk szelídebben, érthetetlennek bizonyultak. A helyzetet - pontosabban a mü megértésének lehetőségét - jelentős mértékben súlyosbították a konkrét körülmények. Elkerülve a büntetőjog világába vezető izgalmakat, annyit árulok csak el, hogy valahol a spanyol tengerpart homokján gyürögettem a posztmodernitás és a jog flörtjéröl szóló alapirodalmat, de nem jutottam vele sokra.

A kötetböl már megismerhetjük, hogy a posztmodernitás a polgári átalakulással született modernitásnak olyan korszakunkra jellemző változata, 


\section{KÖNYVISMERTETÉS}

amelyben megmaradtak a modernitás bizonyos eredeti vívmányai - például a törvény elötti formális egyenlőség -, mások módosultak - például a piac feltételezett mindig előnyös automatikus szabályozó szerepe -, és végül, de nem utolsósorban számos újszerü sajátossága - például az információs és szociális alapjogok, a hátrányos megkülönböztetés tilalma kritériumainak szaporodása, a komplex emberi biztonság, a közbiztonság, a nemzetbiztonság és a nemzetközi biztonság védelmének növekvő jelentősége stb. - született, és a változások természetesen folytatódnak.

Korszakunk egyik népszerü és gyakran idézett szerzője, Samuel $P$. Huntington több kutatás-módszertani ajánlást és szakmai követelményt is megfogalmaz. Szerinte korszakunkat kutató, rendszerező elme számára a valós tudományos teljesítmény azon a képességen alapul, hogy meg kell találnia a csoportképző ismérveket, és képesnek kell lennie arra, hogy a jelenségeket rendszerezze, elkülönítse és összehasonlítsa. Huntington legfontosabb tétele, hogy a világban az új törésvonalak a civilizációk, a vallások, a kultúrák között keletkeznek (lásd A civilizációk összecsapása és a világrend átalakulása címü kötetet). Ezt az álláspontot túlhaladva Ádám Antal így fogalmaz: „korszakunkban csökkenek a feszültségek és szembenállások a világ nagy vallásai között, söt több tárgykörben, föleg az emberiség sorskérdéseiben, az egyénnek és a közösségnek is elönyös erkölcsi szabályok feltárásában és egyeztetésében kibontakozóban van az együttmüködés. Napjainkban az ellentétek - néhány fenyegetö aberráció kivételével - inkább a fundamentalista és nem fundamentalista irányzatok, az eredetinek, hitelesnek nyilvánitott tanitások, valamint az újabb vallási mozgalmak, továbbá a hagyományos mitológiával rendelkezö vallások és az azoktól lényegesen különbözö para-vallási szervezödések között élesednek..."

A két szerző bemutatott nézeteiből kitünik, hogy a szerző látásmódja, tézisei konstruktívabbak, mint Huntingtonéi. Ádám professzor továbbfüzi a gondolatmenetet: ,....nemcsak a vallásoknak vannak közös értékei, hanem a világ nagy kultúráiban és jogrendszereiben is megjelennek azonos vagy hasonló védendö értékek". A lényeges koherens normatív értékek pedig föként bizonyos nemzetközi és szupranacionális rendelkezésekben, valamint a demokratikus jogállami alkotmányokban szerepelnek. Ezeket az alapértékeket pedig egy-egy ország más korszerủ alapértékeivel együtt kell védenie az alkotmánybíráskodás intézményének, valamint az államhatalom egyéb szerveinek és a haladó társadalmi erőknek.

Ádám Antal professor emeritus, volt alkotmánybíró, az MTA doktora, a Pécsi Tudományegyetem honoris causa professzora, Pécs Megyei Jogú Város 
és Jánoshalma város díszpolgára, közel hatszáz publikáció szerzője, több mint hetven kötet szerkesztője, számos tekintélyes kitüntetés viselője a 85. születésnapjára kiadott ünnepi kötetében lépésről lépésre vizsgálja ezt a folyamatot, hiszen elöször a filozófiákról ír, majd vázolja a léttan és a megismerés bölcseleti változatait, csoportosítva ismerteti a nagy filozófiai irányzatokat. A szerző megszokott nagyszerủ megoldása az is, hogy müveiben bemutat egyegy méltatlanul elfelejtett, kitünő tudóst, így például Losonczy István volt pécsi professzort, akinek realista bölcseleti koncepciójáról elismerően ír.

Sokévi kutatómunka termékeiként születtek meg a szerző értéktani és értékszociológiai tanulmányai. Ezek összegzéseként olvashatunk a kötetben az értékek fogalmára vonatkozó irányzatokról és az általa is vallott pluralista értékkoncepcióról, az értékek egymás közötti kapcsolatairól, valamint az értékes és a vele ellentétes értéktelen korrelatív viszonyáról. Tanulságos a Csíkszentmihályi Mihály által kimunkált flow bemutatása is. A kedvelt játékoknak, a szellemi, lelki, érzelmi élvezettel végzett aktivitásoknak a személyiség teljességét lekötő boldogító hatása elönyös, ezért az ilyen erőfeszítések rendszeres bővítésre érdemesek.

Ádám Antal soha nem hagyja figyelmen kívül azt a követelményt, hogy a tudományos igazságok, ha nem is az örökkévalóságnak szólnak, de messze túlmutatnak az aktualitás szerepein. Hazánkban szinte egyedülálló tárgyi tudás birtokában ismerteti és rendszerezi a primitív vallások, az ősi vallások, valamint korszakunk vallásainak hasonló és eltérő összetevőit. Részletesen szól a zsidó és a keresztény bázisú, a hindu, a buddhista, a konfuciánus, a sintoista, a hajdani görög és a római, a kelta, az ősgermán, az ókori eurázsiai, az azték, a maja és az inka vallásokról.

A kötet negyedik része visszatérés a közjoghoz, de még mindig az értéktanok „magasságában”. Itt következnek ugyanis az alkotmányozásra, az alkotmánybíráskodásra, a hazai vallási közösségekre, vagyis a bevett egyházakra és a vallási tevékenységet végző szervezetekre vonatkozó vizsgálódások. A bemutatott könyvben kétszer is szerepel a szerzőnek az a hangsúlyozott állásfoglalása, hogy demokratikus viszonyok között az alkotmányozó hatalom és a törvényhozó hatalom nem eshet egybe. Részletes ajánlást fogalmaz meg az alkotmány kidolgozásának szervezeti és eljárási rendjére, majd határozottan kinyilvánítja, hogy demokratikus jogállam új alkotmányáról csak a népszuverenitás alanya, a választópolgárok összessége dönthet, mégpedig népszavazással.

A szerző korszakunk közhatalmainak bizonyos megnyilvánulásait posztdemokráciának nevezi és ennek jellemzőit huszonhat pontban foglalja össze. 


\section{KÖNYVISMERTETÉS}

Itt látjuk csak igazán a kutatásmódszertan jótékony hatását. Ádám Antal ugyanis a jogszociológia és a politikatudomány empirikus módszereinek felhasználásával, de szilárd közjogi bázison rendszerez, elemez és következtet. Teszi mindezt azzal az igénnyel, hogy kritikai elemzései nem maradnak az éteri világban, hiszen olyan hétköznapokra vonatkoznak, amelyekben a politika túlméretezett. A folyton gazdagodó bölcselet szerepe azonban örök-felette áll a mindennapi politikának. Ádám professzort pedig méltán nevezhetjük a bölcselet egyik hazai doyenjének. Tekintélye pedig kivételes tudásán, rendszeresen bővített ismereteinek kiterjedt és hasznosított bázisán, logikus szerkezetü, gondolatokban, következtetésekben, javaslatokban gazdag müvein és páratlan szellemi élményt nyújtó előadásain alapul.

Készítette: Kondorosi Ferenc 